\title{
Snail-induced EMT promotes cancer stem cell-like properties in head and neck cancer cells
}

\author{
ICHIRO OTA $^{1 *}$, TAKASHI MASUI ${ }^{1 *}$, MIYAKO KURIHARA $^{2}$, JONG-IN YOOK $^{4}$, SHINJI MIKAMI $^{1}$, \\ TAKAHIRO KIMURA ${ }^{1}$, KEIJI SHIMADA ${ }^{3}$, NOBORU KONISHI ${ }^{3}$, KATSUNARI YANE ${ }^{5}$, \\ TOSHIAKI YAMANAKA $^{1}$ and TADASHI KITAHARA ${ }^{1}$

\begin{abstract}
Departments of ${ }^{1}$ Otolaryngology-Head and Neck Surgery, ${ }^{2}$ Molecular Pathology, and ${ }^{3}$ Pathology, Nara Medical University, Kashihara, Nara 634-8522, Japan; ${ }^{4}$ Department of Oral Pathology, Oral Cancer Research Institute, College of Dentistry, Yonsei University, Seoul 120-752, Republic of Korea; ${ }^{5}$ Department of Otolaryngology, Kinki University

School of Medicine, Nara Hospital, Ikoma, Nara 630-0293, Japan
\end{abstract}

Received July 22, 2015; Accepted September 22, 2015

DOI: $10.3892 /$ or.2015.4348

\begin{abstract}
Epithelial-mesenchymal transition (EMT) is a key process involved in the invasion and metastasis of cancer cells. Furthermore, EMT can induce a cancer stem cell (CSC)-like phenotype in a number of tumor types. We demonstrated that Snail is one of the master regulators that promotes EMT and mediates cancer cell migration and invasion in many types of malignancies including head and neck squamous cell carcinoma (HNSCC). In the present study, we investigated the role of Snail in inducing and maintaining CSC-like properties through EMT in HNSCC. We established HNSCC cell lines transfected with Snail. Stem cell markers were evaluated with real-time RT-PCR and western blot analysis. CSC properties were assessed using sphere formation and WST-8 assays as well as chemosensitivity and chick chorioallantoic membrane in vivo invasion assays. Introduction of Snail induced EMT properties in HNSCC cells. Moreover, Snail-induced EMT maintained the CSC-like phenotype, and enhanced sphere formation capability, chemoresistance and invasive ability. These data suggest that Snail could be one of the critical molecular targets for the development of therapeutic strategies for HNSCC.
\end{abstract}

\section{Introduction}

Epithelial-mesenchymal transition (EMT) is an important process in tumor progression that causes epithelial cells to

Correspondence to: Dr Ichiro Ota, Department of Otolaryngology and Head and Neck Surgery, Nara Medical University, 840 Shijo-cho, Kashihara, Nara 634-8522, Japan

E-mail: iota@naramed-u.ac.jp

*Contributed equally

Key words: Snail, epithelial-mesenchymal transition, cancer stem cells, head and neck cancer acquire a migratory mesenchymal phenotype $(1,2)$. EMT is thought to be a critical step in the induction of cell invasion and tumor metastasis (1). Furthermore, it has been shown that cells with an EMT phenotype are more resistant to chemoradiotherapy in regards to head and neck squamous cell carcinoma (HNSCC) (3-6).

It has been indicated in recent studies that EMT induces cancer stem cell (CSC)-like properties in many different types of malignant tumors and that both EMT and a CSC-like phenotype are associated with treatment resistance (7-9). Prince et al demonstrated that the purified $\mathrm{CD} 44^{+}$population of HNSCC cells possesses the self-renewing properties of CSCs (10). Aldehyde dehydrogenase 1 (ALDH1) has also been shown to be a putative marker of CSCs in HNSCC (11). Furthermore, Chen et al showed that CD $44^{+} / \mathrm{ALDH}^{+}$cells resist radiotherapy and may serve as a reservoir for developing tumors and metastasis (6). Additionally, the CD44 $4^{\text {high }} / \mathrm{EGFR}^{\text {low }}$ subpopulation exhibited the EMT phenotype and resistance to treatment in HNSCC (12). Moreover, a high level of expression of variant isoforms of CD44 (CD44v) could suppress the clustering of EGFR at the surface of HNSCC cells and thereby negatively regulate EGFR signaling in the absence of a differentiation stimulus, suggesting that CD44v-negative HNSCC cells rely on EGFR activity for survival (13).

However, the source and the mechanism of development in regards to CSCs have not yet been fully elucidated. Moreover, it has been shown that it is difficult to extract pure CSC populations with only CSC markers such as CD44 and ALDH1. The same result is shown with side populations (14). Therefore, it is necessary not only to identify novel CSC markers but also to clarify the mechanism of CSC development.

Snail, a member of the zinc-finger transcription factor family, plays an important role in EMT by directly repressing epithelial markers such as E-cadherin and by upregulating mesenchymal markers (7,15-19). Several studies have shown that Snail-related transcription factors play a transcriptional and regulatory role in the invasion, metastasis and poor outcome in different type of malignancies, including HNSCC $(20,21)$. These findings suggest that Snail expression may regulate CSC-like properties via EMT in HNSCC. 
We previously demonstrated that Snail overexpression induced EMT, including cancer cell migration and invasion, and promotes CSC-like phenotype such as $\mathrm{CD} 44^{+} / \mathrm{ALDH}^{+}$ in head and neck cancer cells (22). However, the key role of Snail on the stemness of CSC in HNSCC has not been fully elucidated. In the present study, we first demonstrated that Snail-induced EMT gains CSC-like phenotype such as upregulation of stem cell markers, including CD44 and ALDH1, and enhanced CSC-like properties such as sphere formation capability, chemoresistance and in vivo cancer invasion and metastasis in HNSCC.

\section{Materials and methods}

Cell lines and culture. Human HNSCC cells, SAS and HSC-4, were employed in the present study. SAS and HSC-4 cells, obtained from the Japanese Cancer Research Resource Bank (Tokyo, Japan), were cultured in Dulbecco's modified Eagle's medium (DMEM) supplemented with 10\% heat-inactivated fetal bovine serum (FBS) (both from Invitrogen, Carlsbad, CA, USA), $100 \mathrm{U} / \mathrm{ml}$ penicillin and $100 \mathrm{mg} / \mathrm{ml}$ streptomycin (Gibco, Grand Island, NY, USA) at $37^{\circ} \mathrm{C}$ in $5 \% \mathrm{CO}_{2}$.

Transient transfection. The cDNA fragment encoding human Snail (NM_005985.2) was inserted into the pCR 3.1 mammalian expression vector (Invitrogen). For transient transfection, SAS and HSC-4 cells $\left(1.5 \times 10^{5}\right.$ cells) were plated into 6-well culture plates and allowed to adhere for $12 \mathrm{~h}$. Then, the cells were transfected with $2 \mu \mathrm{g}$ of either pCR 3.1-Snail or pCR 3.1-vector (without insert DNA) with Lipofectamine 2000 reagent (Invitrogen) according to the manufacturer's instructions. We established SAS-Snail and HSC-4-Snail as Snail-expressing cell lines and their respective control cell lines.

Immunoblot analysis and antibodies. Total protein extracts were prepared according to the freeze-thawing lysis method, and protein concentrations were measured with a bovine serum albumin (BSA) protein assay. Samples of extract containing $20 \mu \mathrm{g}$ of protein were then separated by SDS-PAGE and transferred to polyvinylidene difluoride membranes. After washing with phosphate-buffered saline with Tween-20 (PBST), the membranes were incubated first with rabbit anti-Nanog, rabbit anti-Oct4, rabbit anti-ABCG2, rabbit anti-EGFR and rabbit anti-pEGFR (Cell Signaling Technology, Danvers, MA, USA; diluted 1:1,000), rabbit anti-Sox 2 and rabbit anti-Bmi1 (Abcam, Cambridge, MA, USA; diluted 1:1,000) antibodies at $4^{\circ} \mathrm{C}$ overnight and then with peroxidase-conjugated secondary anti-rabbit antibody or goat immunoglobulin G (IgG) (diluted 1:1,000; Cell Signaling Technology) for $1 \mathrm{~h}$. After rinsing in PBST, immunodetection was accomplished using an ECL western blot analysis detection reagent and analysis system. The membranes were subsequently exposed to X-ray film as previously described (23).

Real-time RT-PCR. Total RNA was isolated from each cell line using the RNeasy Mini kit (Qiagen, Hilden, Germany). cDNA was then reverse transcribed using ReverTra Ace ${ }^{\circledR}$ qPCR RT Master Mix with gDNA Remover (Toyobo Life Science, Tokyo, Japan) according to the manufacturer's instructions. Real-time RT-PCR was then carried out using the
Table I. Primers for real-time RT-PCR.

Gene Primer sequence

\begin{tabular}{ll}
\hline ABCG2 & S 5'-CATGTACTGGCGAAGAATATTTGGT-3' \\
(NM_004827) & A 5'-CACGTGATTCTTCCACAAGCC-3' \\
Bmil & S 5'-AAATGCTGGAGAACTGGAAAG-3' \\
(NM_005180) & A 5'-CTGTGGATGAGGAGACTGC-3' \\
Nanog & S 5'-ATTCAGGACAGCCCTGATTCTTC-3' \\
(NM_024865) & A 5'-TTTTTGCGACACTCTTCTCTGC-3' \\
Oct4 & S 5'-GTGGAGAGCAACTCCGATG-3' \\
(NM_002701) & A 5'-TGCTCCAGCTTCTCCTTCTC-3' \\
Sox2 & S 5'-CGAGTGGAAACTTTTGTCGGA-3' \\
(NM_003106) & A 5'-TGTGCAGCGCTCGCAG-3' \\
GAPDH & S 5'-CATCATCCCTGCCTCTACTG-3' \\
(NM_002046) & A 5'-GCCTGCTTCACCACCTTC-3'
\end{tabular}

$\mathrm{S}$, sense; $\mathrm{A}$, antisense.

primers shown in Table I and EXPRESS SYBR ${ }^{\circledR}-$ GreenER $^{\mathrm{TM}}$ qPCR SuperMix with premixed ROX (Invitrogen). PCR was performed with an initial step of $3 \mathrm{~min}$ at $95^{\circ} \mathrm{C}$ followed by 40 cycles of $3 \mathrm{sec}$ at $95^{\circ} \mathrm{C}$ and $20 \mathrm{sec}$ at $60^{\circ} \mathrm{C}$. The level of target mRNA was normalized to the mRNA level of GAPDH as an internal standard.

Sphere formation assay. The capability of self-renewal was assessed using 96-well NanoCulture plates (Scivax, Tokyo, Japan). Cells $\left(1 \times 10^{4}\right)$ were seeded and cultured for 1 week in DMEM supplemented with $10 \%$ FBS or serum-free medium, and phase-contrast images were obtained.

Chemotherapy of the cultured cells. Chemosensitivity was assessed using the Cell Counting Kit-8 (WST-8 cleavage; Dojindo, Mashikimachi, Japan) as previously described (23). The cells were seeded into 96-well plates at an initial density of $4 \times 10^{3}$ cells/well and incubated for $24 \mathrm{~h}$. For chemotherapy, cisplatin (Nihon Kayaku Co., Tokyo, Japan) at a concentration of $1.0 \mu \mathrm{M}$ was added to each well. Following incubation for an additional $48 \mathrm{~h}, 10 \mu \mathrm{l}$ of WST-8 solution was added to each well, and the plate was incubated for a further $2 \mathrm{~h}$. The absorbance of each well at $450 \mathrm{~nm}$ (reference wavelength at $620 \mathrm{~nm}$ ) was measured by a Multiscan FC microplate photometer (Thermo Scientific). The measurement was repeated at least three times for each cell line.

Chick chorioallantoic membrane (CAM) in vivo invasion assay. The CAM in vivo invasion assay was conducted using 11-day-old chick embryos wherein HSC-4 or the transfected cells $\left(10^{5}\right.$ cells labeled with green Fluoresbrite carboxylated polystyrene nanospheres of 45-nm diameter; Polysciences) were seeded atop the CAM and incubated for three days as previously described $(24,25)$. The CAM was dropped without damaging the epithelial basement membrane (BM) by applying gentle negative pressure at the air sac, and an opening of $\sim 1 \mathrm{~cm}^{2}$ was cut in the shell above the CAM with an electric drill. 
A

SAS

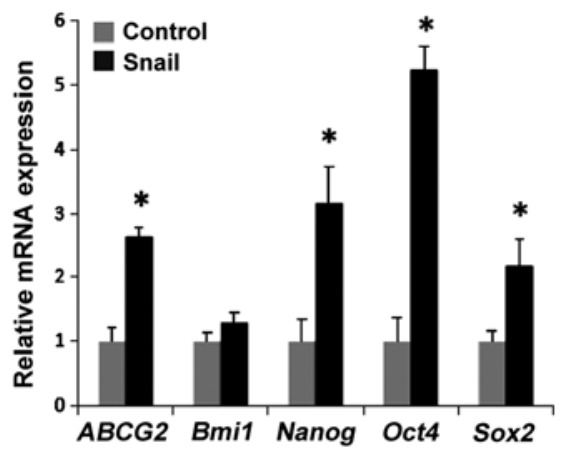

HSC-4

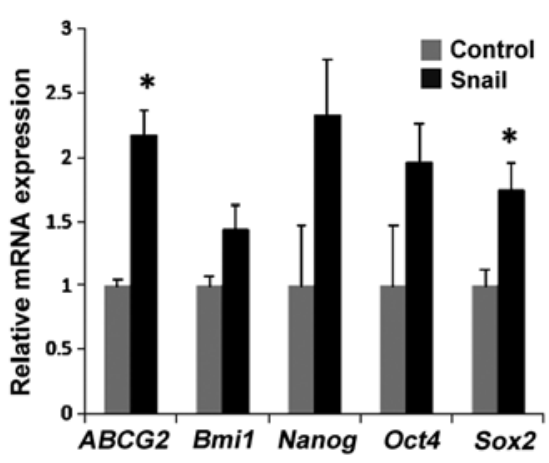

B

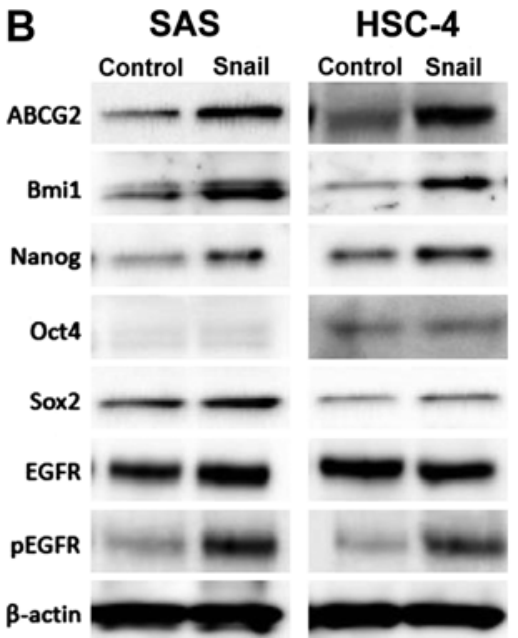

Figure 1. Snail induces expression of several stem cell markers in SAS and HSC-4 cells. (A) Relative expression of mRNA-encoding stem cell genes ABCG2, Bmil, Nanog, Oct4 and Sox2 normalized to the endogenous control GAPDH. (B) The level of each protein was determined by western blot analysis with $\beta$-actin used as the internal control. Data represent the mean $\pm \mathrm{SE}$. "P<0.05.

SAS

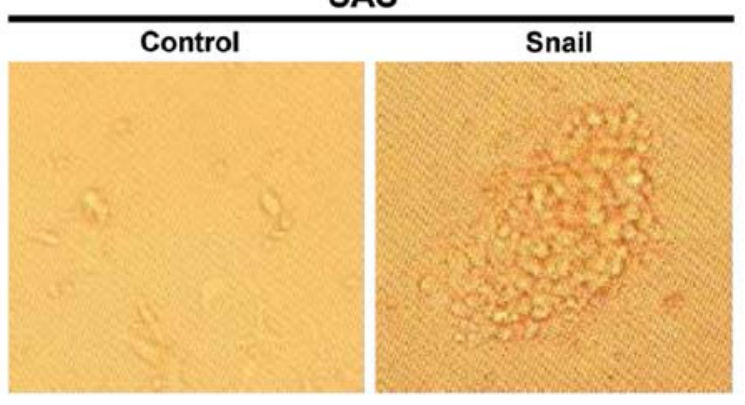

HSC-4

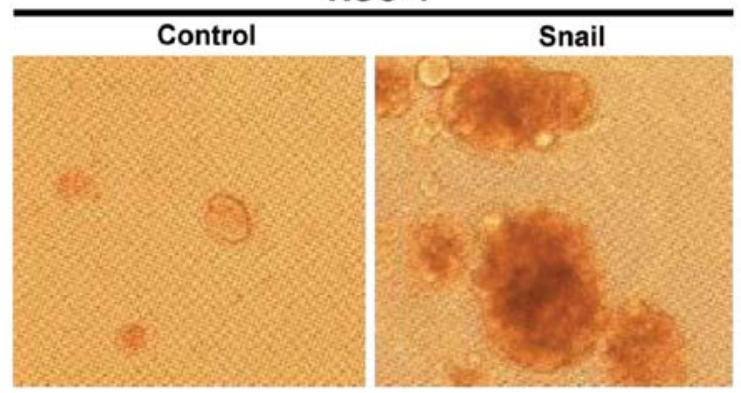

Figure 2. Transfection of Snail increases tumor sphere-forming capability. Tumor sphere-forming capability was assessed by a sphere formation assay. Cells were seeded and cultured for 1 week.

Statistical analysis. Data are presented as the mean \pm standard error (SE). Experimental differences between groups were assessed with a t-test. The differences were considered to indicate a statistically significant result at $\mathrm{P}<0.05$.

\section{Results}

Snail expression induces a CSC-like phenotype. To elucidate that EMT by Snail expression induces a stem cell-like phenotype in HNSCC cells, we investigated the expression of CSC surface markers in HNSCC cells. We previously demonstrated that expression of both CD44 and ALDH1 increased in SAS-Snail and HSC-4-Snail cells compared with their control cells (22). RT-PCR analysis revealed that mRNA levels of several stem cell markers, Bmil, Nanog, Oct4, Sox 2 and ABCG2, which are drug-resistant proteins, were high in the Snail-transfected cells compared with the levels in the controls (Fig. 1A). Moreover, at the protein level, Nanog, Bmil and ABCG2 were also upregulated in the Snailtransfected cells, whereas the expression of Oct4 and Sox 2 showed no difference between the Snail-expressing cells and the controls (Fig. 1B). These data revealed that Snail-induced
EMT elicits a CSC-like phenotypic change as $\mathrm{CD}_{4} 4^{+} / \mathrm{ALDH}^{+}$, and directly regulates the expression of Nanog, Bmil and ABCG2. In addition, there were no differences in the level of EGFR protein between the Snail-transfected cells and the controls, whereas, the levels of phospho-EGFR protein increased in the Snail-transfected cells compared with that in the control (Fig. 1B).

Snail induces CSC properties. The transfection of Snail induced tumor sphere-forming capability in the SAS and HSC-4 cells, but not in the control cells (Fig. 2). Furthermore, the cells transfected with Snail showed significantly low chemosensitivity at $1.0 \mu \mathrm{M}$ of cisplatin, as compared with the control cells (Fig. 3). Thus, these data revealed that the acquisition of a CSC-like phenotype caused by Snail-induced EMT results in enhancement of the ability of sphere formation and chemoresistance in the HNSCC cells.

Snail induces EMT as a CSC property in vivo. We previously demonstrated that Snail-regulated EMT promotes CSC properties, including cell migration and invasion as well as E-cadherin suppression in HNSCC cells in vitro (22). Snail was 


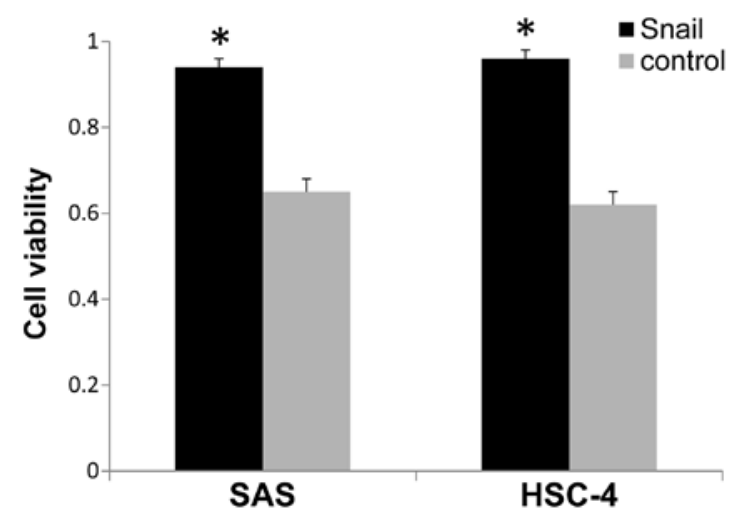

Figure 3. Snail expression enhances the chemoresistance to cisplatin in SAS and HSC-4 cells. Cell viability was assessed using WST-8 assay for chemosensitivity. Cells were incubated for $24 \mathrm{~h}$. For chemotherapy, the cells were treated with $1.0 \mu \mathrm{M}$ of cisplatin. Following an additional $48 \mathrm{~h}$, cell viability was determined by WST -8 assay. Data are shown as the mean $\pm \mathrm{SE}$. ${ }^{*} \mathrm{P}<0.05$.

also functional in inducing in vivo cancer invasive progression of non-invasive SAS and HSC-4 cells, as noted in the crossing of cells into the BM in the CAM assay (Fig. 4).

\section{Discussion}

The identification of cell surface-specific markers of CSCs is critical for the possible establishment of target-specific cancer therapies. CD44 (10) and ALDH1 (11) have been reported to represent candidate markers of CSCs in HNSCC. Recently, CD271 (26) and CD10 (27) have been identified as additional markers of CSCs in HNSCC. However, it is difficult to extract CSCs selectively with such markers only. Several studies have indicated that there could be key markers of CSCs that regulate stemness genes, such as Bmi1, Nanog, Oct4, Sox 2 and ABCG2 as follows.

Bmil has been demonstrated to play a role in the tumorigenesis of HNSCC $(28,29)$. Expression of Bmil, ALDH1 and Snail could be associated with the maintenance of stemness in CSCs and correlate with poor overall survival in HNSCC patients (30). Additionally, Bmil can regulate Snail and ALDH1 in inducing EMT and CSC properties (30). In the present study, we obtained results consistent with those in our previous study (22).

Nanog maintains the pluripotency of embryonic stem cells and functionally blocks differentiation $(31,32)$. Recent studies have demonstrated that Nanog promotes CSC properties, and the downregulation of Nanog inhibits sphere formation and tumor development (33-36). Another study suggested that Nanog was upregulated by TGF- $\beta$ through Smad signaling and that Snail directly regulates Nanog promoter activity (37). Nanog expression was also upregulated in the present study, whereas there were no significantly differences in the expression of Oct4 and Sox 2 between Snail-transfected cells and the controls. A previous study showed that Oct 4 and Sox 2 regulate Nanog expression (38). Therefore, direct regulation against the Nanog promoter by Snail may result in the suppression of Oct4 and Sox2.

Yoshikawa et al showed that the expression of EGFR was low in CSCs, but high in non-CSCs. They suggested that a high level of expression of variant isoforms of CD44 (CD44v) could suppress the clustering of EGFR at the surface

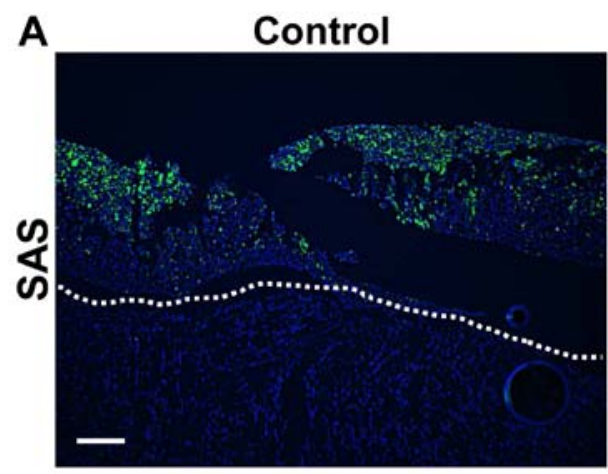

B
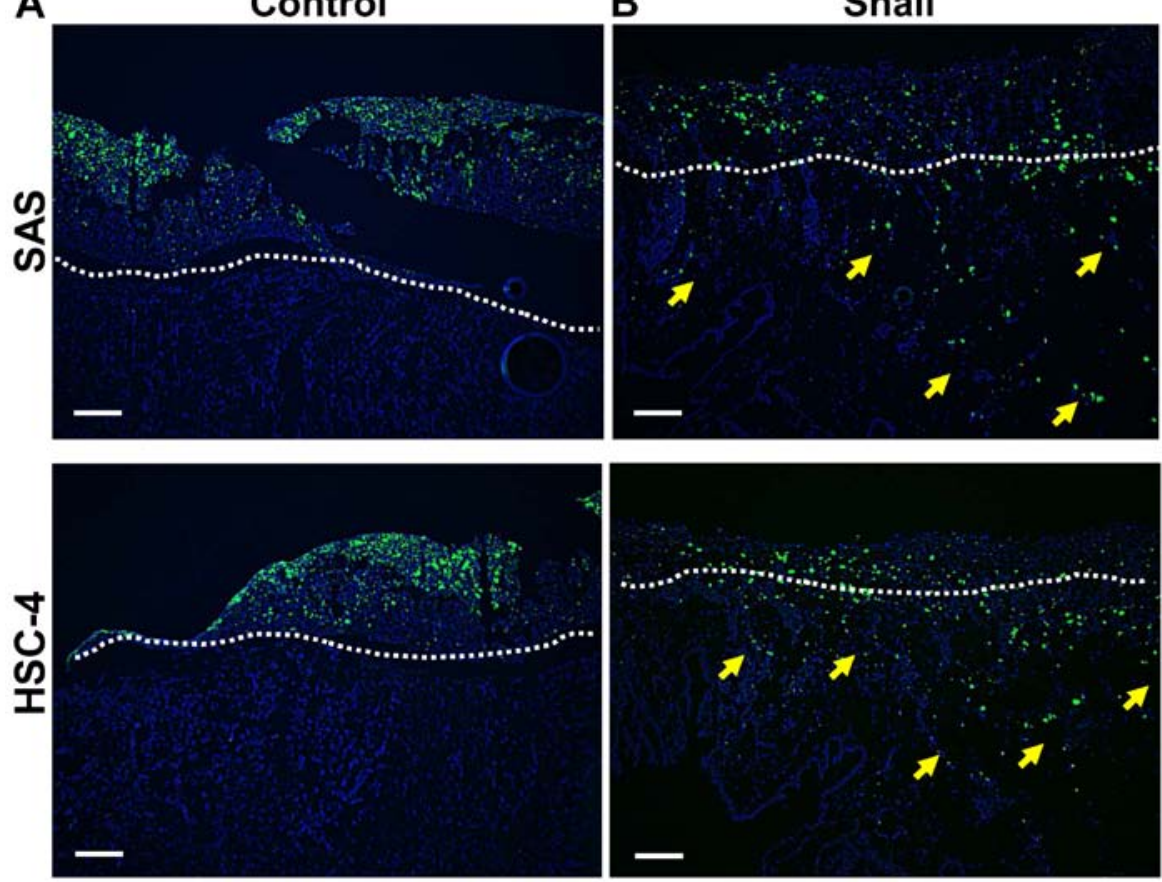

Figure 4. Snail expression increases in vivo cell invasion in head and neck cancer cells. The non-invasive SAS and HSC-4 cells were transiently co-transfected with either a control (A) or Snail (B) labeled with green fluorescent nanospheres, respectively. The cells were cultured atop the embryonic chick chorioallantoic membrane (CAM) for 3 days and the fixed tissue sections then were examined by fluorescence microscopy. The upper face of the CAM is indicated by dashed white lines; invasive cancer cells (green) are denoted by yellow arrows. Scale bars, $200 \mu \mathrm{m}$. 
of HNSCC cells and thereby negatively regulate EGFR signaling in the absence of a differentiation stimulus, and that CD44v-negative HNSCC cells rely on EGFR activity for survival (13). It has been suggested that the suppression of differentiation and treatment resistance in CSCs could be attributed to CD44v-positive and EGFR-negative expression. In the present study, Snail overexpression induced CSC-like properties, while there was no significantly difference in the expression of EGFR between the Snail-transfected cells and the controls. Furthermore, the expression of phospho-EGFR was enhanced in the Snail-transfected cells compared with the controls. However, this result is considered to be compatible with the findings in the previous study. It was predicted from the present study that the CSC-like properties acquired by Snail occurred not in all cells, but in a portion of them. This raises the possibility that upregulation of phospho-EGFR occurred in non-CSCs around CSCs. Wang et al showed that reduction in E-cadherin resulted in upregulation of EGFR transcriptionally and activation of EGFR resulted in overexpression of Snail (39). It was suggested that Snail could not only induce CSC-like properties, but also phosphorylates EGFR in non-CSCs, and it contributed to the maintenance of the microenvironment by interaction between CSCs and nonCSCs. Although the precise involvement of CD44 and EGFR expression by Snail in the regulation of CSCs remains to be elucidated, they may be involved in a latent effect. The critical mechanisms remain to be further investigated. The majority of studies on CSCs have been performed in vitro to evaluate clinical cancer therapies. Therefore, it should be noted that the results of in vitro studies on CSCs cannot be translated to the same cells in vivo. Although it is still too early to discuss its clinical efficiency, these data could support the hypothesis that the interaction between CSCs and non-CSCs contributes to cell proliferation and treatment resistance.

In addition, the upregulation of ABCG2 expression was also observed in the Snail-transfected cells. However, higher expression of ABCG2 was observed not in $\mathrm{ALDH}^{+}$cells, but in ALDH cells around CSCs (40). This suggests that ABCG2 itself is not a CSC marker, but the interaction between CSCs and the cells around CSCs results in upregulation of ABCG2. The upregulation of ABCG2 in the present study could similarly support the possibility that Snail contributes to the interaction between CSCs and non-CSCs.

Furthermore, we first showed that Snail regulates cancer cell invasion through EMT as a CSC-like property in HNSCC cells in vivo as well as in vitro (22). These data suggest that Snail can promote cancer invasion and metastasis as well as maintain the stemness similar to CSCs.

In summary, we demonstrated the possibility that Snail induces CSC-like properties through EMT and maintains stemness by upregulating various CSC markers. However, other transcription factors of EMT as well as Snail could be involved in the maintenance of CSCs and the microenvironment. These interactions between various CSC- and EMT-relating genes make it difficult to select a pure CSC population. Snail-induced EMT is also considered to play an essential role in tumor progression, such as cancer invasion and metastasis in vivo. Although the critical mechanisms remain to be further investigated, Snail could prove to be one of the valid targets in the treatment for HNSCC.

\section{Acknowledgements}

The present study was supported in part by Grants-in Aids for Scientific Research from the Ministry of Education, Culture, Sports, Science and Technology of Japan.

\section{References}

1. Thiery JP and Sleeman JP: Complex networks orchestrate epithelial-mesenchymal transitions. Nat Rev Mol Cell Biol 7: 131-142, 2006.

2. Hay ED: The mesenchymal cell, its role in the embryo, and the remarkable signaling mechanisms that create it. Dev Dyn 233: 706-720, 2005.

3. Hsu DS, Lan HY, Huang CH, Tai SK, Chang SY, Tsai TL, Chang CC, Tzeng CH, Wu KJ, Kao JY, et al: Regulation of excision repair cross-complementation group 1 by Snail contributes to cisplatin resistance in head and neck cancer. Clin Cancer Res 16: 4561-4571, 2010.

4. Batlle E, Sancho E, Francí C, Domínguez D, Monfar M, Baulida J and García De Herreros A: The transcription factor snail is a repressor of E-cadherin gene expression in epithelial tumour cells. Nat Cell Biol 2: 84-89, 2000.

5. Chiou SH, Kao CL, Chen YW, Chien CS, Hung SC, Lo JF Chen YJ, Ku HH, Hsu MT and Wong TT: Identification of CD133-positive radioresistant cells in atypical teratoid/rhabdoid tumor. PLoS One 3: e2090, 2008.

6. Chen YC, Chang CJ, Hsu HS, Chen YW, Tai LK, Tseng LM, Chiou GY, Chang SC, Kao SY, Chiou SH, et al: Inhibition of tumorigenicity and enhancement of radiochemosensitivity in head and neck squamous cell cancer-derived ALDH1-positive cells by knockdown of Bmi-1. Oral Oncol 46: 158-165, 2010.

7. Thiery JP, Acloque H, Huang RY and Nieto MA: Epithelialmesenchymal transitions in development and disease. Cell 139: 871-890, 2009.

8. Yang AD, Fan F, Camp ER, van Buren G, Liu W, Somcio R, Gray MJ, Cheng H, Hoff PM and Ellis LM: Chronic oxaliplatin resistance induces epithelial-to-mesenchymal transition in colorectal cancer cell lines. Clin Cancer Res 12: 4147-4153, 2006.

9. Mani SA, Guo W, Liao MJ, Eaton EN, Ayyanan A, Zhou AY, Brooks M, Reinhard F, Zhang CC, Shipitsin M, et al: The epithelial-mesenchymal transition generates cells with properties of stem cells. Cell 133: 704-715, 2008.

10. Prince ME, Sivanandan R, Kaczorowski A, Wolf GT, Kaplan MJ, Dalerba P, Weissman IL, Clarke MF and Ailles LE: Identification of a subpopulation of cells with cancer stem cell properties in head and neck squamous cell carcinoma. Proc Natl Acad Sci USA 104: 973-978, 2007.

11. Chen YC, Chen YW, Hsu HS, Tseng LM, Huang PI, Lu KH, Chen DT, Tai LK, Yung MC, Chang SC, et al: Aldehyde dehydrogenase 1 is a putative marker for cancer stem cells in head and neck squamous cancer. Biochem Biophys Res Commun 385: 307-313, 2009.

12. La Fleur L, Johansson AC and Roberg K: A CD $44^{\text {high }} / E_{G F R}{ }^{\text {low }}$ subpopulation within head and neck cancer cell lines shows an epithelial-mesenchymal transition phenotype and resistance to treatment. PLoS One 7: e44071, 2012.

13. Yoshikawa M, Tsuchihashi K, Ishimoto T, Yae T, Motohara T, Sugihara E, Onishi N, Masuko T, Yoshizawa K, Kawashiri S, et al: $\mathrm{xCT}$ inhibition depletes CD44v-expressing tumor cells that are resistant to EGFR-targeted therapy in head and neck squamous cell carcinoma. Cancer Res 73: 1855-1866, 2013.

14. Burkert J, Otto WR and Wright NA: Side populations of gastrointestinal cancers are not enriched in stem cells. J Pathol 214: 564-573, 2008

15. Moody SE, Perez D, Pan TC, Sarkisian CJ, Portocarrero CP, Sterner CJ, Notorfrancesco KL, Cardiff RD and Chodosh LA: The transcriptional repressor Snail promotes mammary tumor recurrence. Cancer Cell 8: 197-209, 2005.

16. Peinado H, Olmeda D and Cano A: Snail, Zeb and bHLH factors in tumour progression: An alliance against the epithelial phenotype? Nat Rev Cancer 7: 415-428, 2007.

17. Debies MT, Gestl SA, Mathers JL, Mikse OR, Leonard TL, Moody SE, Chodosh LA, Cardiff RD and Gunther EJ: Tumor escape in a Wntl-dependent mouse breast cancer model is enabled by $\mathrm{p} 19^{\text {Arf }} / \mathrm{p} 53$ pathway lesions but not $\mathrm{p} 16^{\text {Ink4a }}$ loss. J Clin Invest 118: 51-63, 2008 . 
18. Kudo-Saito C, Shirako H, Takeuchi T and Kawakami Y: Cancer metastasis is accelerated through immunosuppression during Snail-induced EMT of cancer cells. Cancer Cell 15: 195-206, 2009.

19. Vincent T, Neve EP, Johnson JR, Kukalev A, Rojo F, Albanell J, Pietras K, Virtanen I, Philipson L, Leopold PL, et al: A SNAIL1-SMAD3/4 transcriptional repressor complex promotes TGF-beta mediated epithelial-mesenchymal transition. Nat Cell Biol 11: 943-950, 2009.

20. Yokoyama K, Kamata N, Hayashi E, Hoteiya T, Ueda N, Fujimoto R and Nagayama M: Reverse correlation of E-cadherin and snail expression in oral squamous cell carcinoma cells in svitro. Oral Oncol 37: 65-71, 2001.

21. Peinado H, Ballestar E, Esteller M and Cano A: Snail mediates E-cadherin repression by the recruitment of the Sin3A/histone deacetylase 1 (HDAC1)/HDAC2 complex. Mol Cell Biol 24 306-319, 2004.

22. Masui T, Ota I, Yook JI, Mikami S, Yane K, Yamanaka T and Hosoi H: Snail-induced epithelial-mesenchymal transition promotes cancer stem cell-like phenotype in head and neck cancer cells. Int J Oncol 44: 693-699, 2014.

23. Hayashi K, Motoyama S, Sugiyama T, Izumi J, Anbai A, Nanjo H, Watanabe H, Maruyama K, Minamiya Y, Koyota S, et al: REG Ialpha is a reliable marker of chemoradiosensitivity in squamous cell esophageal cancer patients. Ann Surg Oncol 15: 1224-1231, 2008.

24. Yook JI, Li XY, Ota I, Hu C, Kim HS, Kim NH, Cha SY, Ryu JK, Choi YJ, Kim J, et al: A Wnt-Axin2-GSK3beta cascade regulates Snaill activity in breast cancer cells. Nat Cell Biol 8: 1398-1406, 2006.

25. Ota I, Li XY, Hu Y and Weiss SJ: Induction of a MT1-MMP and MT2-MMP-dependent basement membrane transmigration program in cancer cells by Snaill. Proc Natl Acad Sci USA 106: 20318-20323, 2009.

26. Imai T, Tamai K, Oizumi S, Oyama K, Yamaguchi K, Sato I, Satoh K, Matsuura K, Saijo S, Sugamura K, et al: CD271 defines a stem cell-like population in hypopharyngeal cancer. PLoS One 8: e62002, 2013.

27. Fukusumi T, Ishii H, Konno M, Yasui T, Nakahara S, Takenaka Y, Yamamoto Y, Nishikawa S, Kano Y, Ogawa H, et al: CD10 as a novel marker of therapeutic resistance and cancer stem cells in head and neck squamous cell carcinoma. Br J Cancer 111: 506-514, 2014.

28. Brunner M, Thurnher D, Pammer J, Geleff S, Heiduschka G, Reinisch CM, Petzelbauer P and Erovic BM: Expression of VEGF-A/C, VEGF-R2, PDGF-alpha/beta, c-kit, EGFR, Her-2/Neu, Mcl-1 and Bmi-1 in Merkel cell carcinoma. Mod Pathol 21: 876-884, 2008
29. Zhang P, Zhang Y, Mao L, Zhang Z and Chen W: Side population in oral squamous cell carcinoma possesses tumor stem cell phenotypes. Cancer Lett 277: 227-234, 2009.

30. Yu CC, Lo WL, Chen YW, Huang PI, Hsu HS, Tseng LM, Hung SC, Kao SY, Chang CJ and Chiou SH: Bmi-1 regulates Snail expression and promotes metastasis ability in head and neck squamous cancer-derived ALDH1 positive cells. J Oncol 2011: pii: 609259, 2011.

31. Chambers I, Colby D, Robertson M, Nichols J, Lee S, Tweedie S and Smith A: Functional expression cloning of Nanog, a pluripotency sustaining factor in embryonic stem cells. Cell 113: 643-655, 2003.

32. Abelev GI and Lazarevich NL: Control of differentiation in progression of epithelial tumors. Adv Cancer Res 95: 61-113, 2006.

33. Jeter CR, Badeaux M, Choy G, Chandra D, Patrawala L, Liu C, Calhoun-Davis T, Zaehres H, Daley GQ and Tang DG: Functional evidence that the self-renewal gene $N A N O G$ regulates human tumor development. Stem Cells 27: 993-1005, 2009.

34. Jeter CR, Liu B, Liu X, Chen X, Liu C, Calhoun-Davis T, Repass J, Zaehres H, Shen JJ and Tang DG: NANOG promotes cancer stem cell characteristics and prostate cancer resistance to androgen deprivation. Oncogene 30: 3833-3845, 2011.

35. Chiou SH, Wang ML, Chou YT, Chen CJ, Hong CF, Hsieh WJ, Chang HT, Chen YS, Lin TW, Hsu HS, et al: Coexpression of Oct4 and Nanog enhances malignancy in lung adenocarcinoma by inducing cancer stem cell-like properties and epithelialmesenchymal transdifferentiation. Cancer Res 70: 10433-10444, 2010.

36. Chen C, Wei Y, Hummel M, Hoffmann TK, Gross M, Kaufmann AM and Albers AE: Evidence for epithelial-mesenchymal transition in cancer stem cells of head and neck squamous cell carcinoma. PLoS One 6: e16466, 2011.

37. Dang H, Ding W, Emerson D and Rountree CB: Snaill induces epithelial-to-mesenchymal transition and tumor initiating stem cell characteristics. BMC Cancer 11: 396, 2011.

38. Niwa H: Molecular mechanism to maintain stem cell renewal of ES cells. Cell Struct Funct 26: 137-148, 2001.

39. Wang D, Su L, Huang D, Zhang H, Shin DM and Chen ZG Downregulation of E-Cadherin enhances proliferation of head and neck cancer through transcriptional regulation of EGFR. Mol Cancer 10: 116, 2011.

40. Emmink BL, Van Houdt WJ, Vries RG, Hoogwater FJ, Govaert KM, Verheem A, Nijkamp MW, Steller EJ, Jimenez CR, Clevers H, et al: Differentiated human colorectal cancer cells protect tumor-initiating cells from irinotecan. Gastroenterology 141: 269-278, 2011. 